\title{
Effect of grafting on the control of gummy stem blight in muskmelons
}

\section{Efeito da enxertia no controle do crestamento gomoso em meloeiro}

\author{
Francielli Gasparotto ${ }^{1}$; Ricardo Ribeiro de Oliveira ${ }^{2}$; Marcelo Paes Penharbel ${ }^{3}$; \\ Dauri José Tessmann ${ }^{4}$; Jefferson Fernandes do Nascimento ${ }^{5}$; João Batista Vida ${ }^{6 *}$
}

\begin{abstract}
Gummy stem blight, caused by Didymella bryoniae, is the most important fungal diseases of muskmelons cultivated in protected environments in Brazil. Fungicides are used to control this disease, and little is known about the effectiveness of alternative control methods. The aim of this study was to evaluate the effect of grafting on the control of gummy stem blight in four muskmelon hybrids. The hybrids Bonus II, Sunrise, Louis and Prince hakusho were grafted onto the squash hybrid Shelper, which is immune to D. bryoniae. Two experiments were conducted, one in greenhouse with artificial inoculation of the pathogen and the other in protected environment using crop residues and soil infected with the pathogen. Under greenhouse conditions, mycelial discs of the pathogen were inoculated onto the hypocotyl or at the union graft/rootstock region of the grafted plants and onto ungrafted plants of each hybrid. By growing these four melon hybrids in a protected environment, the effect of grafting on the control of gummy stem blight could be studied. When these melons were grown in the greenhouse or in a protected environment, grafting significantly reduced the growth of gummy stem blight in all four melon hybrids. For grafted hybrid plants inoculated at the hypocotyl, the disease severity decreased by $34.1 \%, 33.8 \%, 51.1 \%$ and $48.0 \%$ for Sunrise, Bonus II, Louis and Prince hakusho, respectively, compared to ungrafted plants. For grafted plants inoculated at the union graft/rootstock region, the disease severity decreased by $54.3 \%, 57.3 \%, 54.1 \%$ and $44.6 \%$, respectively. For melons grown in protected environments, grafting reduced the severity of gummy stem blight in the four melon hybrids by $34.3 \%, 34.8 \%, 45.8 \%$ and $49.6 \%$, respectively. Thus, grafting onto immune rootstocks significantly reduced the severity of $D$. bryoniae in the four muskmelon hybrids grown under greenhouse and protected environment conditions.
\end{abstract}

Key words: Alternative control. Cucumis melo L. Didymella bryoniae. Integrated management. Sustainability.

\section{Resumo}

O crestamento gomoso, causado por Didymella bryoniae constitui-se na doença fúngica mais importante para cultura de melão nobre em ambiente protegido no Brasil. Basicamente o controle desta doença é realizado com fungicidas e pouco se sabe sobre a eficiência de medidas alternativas no controle da mesma. O objetivo desse trabalho foi avaliar o efeito da enxertia no controle do crestamento gomoso em quatro híbridos de melão nobre. Os híbridos Bonus II, Sunrise, Louis e Prince hakusho foram

\footnotetext{
${ }^{1}$ Prof ${ }^{a}$ Titular, Centro Universitário Cesumar, Unicesumar, Maringá, PR, Brasil. E-mail: francielli.gasparotto@unicesumar.edu.br

2 Pós-Doutorando em Agronomia, Programa de Pós-Graduação em Agronomia, Universidade Estadual de Maringá, UEM, Maringá, PR, Brasil. E-mail: ollivveira@yahoo.com.br

${ }^{3}$ Eng $^{\circ}$ Agr $^{\circ}$, Mestre em Proteção de Plantas, Marialva, PR, Brasil. E-mail: paesagro@gmail.com

${ }^{4}$ Prof. Associado, UEM, Maringá, PR, Brasil. E-mail: djtessmann@uem.br

5 Prof. Titular, Universidade Federal de Roraima, UFRR, Paricarana, RR, Brasil. E-mail: jefferson.fernandes@ufrr.br

${ }^{6}$ Prof. Titular, UEM, Maringá, PR, Brasil. E-mail: jbvida@uem.br

* Author for correspondence
} 
enxertados no hibrido de abóbora Shelper, imune a D. bryoniae. Foram realizados dois experimentos, um em casa de vegetação com inoculação artificial do patógeno e outro em condições de ambiente protegido utilizando restos culturais e solo infectado com o patógeno. Em condições de casa de vegetação, utilizou-se um disco de micélio do patógeno para inocular as plantas no hipocótilo na região do enxerto e também plantas pé-franco de cada híbrido. Em casa-de-vegetação e na cultura de melão em ambiente protegido houve efeito significativo da enxertia na redução de crestamento gomoso nos quatro híbridos de melão. Para a inoculação no hipocótilo do enxerto em plantas enxertadas houve redução da severidade da doença em 34,1\%, 33,8\%, 51,1\% e 48,0\% para Sunrise, Bonus II, Louis e Prince hakusho, respectivamente, em relação às plantas pé-franco. Para inoculação na região da enxertia houve redução da severidade da doença em $54,3 \%, 57,3 \%, 54,1 \%$ e $44,6 \%$, respectivamente. $\mathrm{Na}$ cultura de melão em ambiente protegido, o percentual de redução da severidade do crestamento gomoso proporcionado pela enxertia foi de $34,3 \%, 34,8 \%, 45,8 \%$ e $49,6 \%$, respectivamente. Assim, a enxertia em porta-enxertos imunes reduziu significativamente a severidade de $D$. bryoniae nos quatro híbridos de meloeiro cultivados em casa de vegetação e em ambiente protegido.

Palavras-chave: Controle alternativo. Cucumis melo L. Didymella bryoniae. Manejo integrado. Sustentabilidade.

In southern and southeastern Brazil, muskmelons (Cucumis melo L. var. reticulatus, C. melo var. cantalupensis) are one of the most important crops and are cultivated in protected environments, such as plastic greenhouses. Gummy stem blight, caused by Didymella bryoniae (Fuckel) Rehm (anamorph Ascochyta cucumis Fautrey \& Roum.), is the most important disease of this crop in this agro system. The damage caused by this disease can reach $100 \%$, leading to crop loss when effective control measures are not used or are inadequate (VIDA et al., 2004a, 2004b).

To control gummy stem blight, melon crops are usually sprayed with fungicides (KUROZAWA et al., 2005; VIDA et al., 2001). Once the pathogen has infected a melon plant, the initial disease symptoms occur on the stems near the soil line (VIDA et al., 2004a). It is difficult for the chemical control agents to reach their biological target in this location, decreasing their efficacy. Therefore, the use of alternative control measures in conjunction with chemical control methods may significantly increase the effectiveness of efforts to combat this disease.

For some plant diseases, alternative disease control measures have seldom proven practical. The factors that contribute to this situation include limited available information about the effectiveness of alternative methods on a practical scale and the need for additional complementary control measures in many cases. For D. bryoniae, the practice of grafting susceptible plants onto immune rootstocks can have an additive effect when combined with chemical control methods in cucurbit crops. In Brazil, grafting pumpkin rootstock Shelper is often used to produce parthenocarpic cucumbers (SANTOS; GOTO, 2003) and has a high potential for success in melon crops (RIZZO et al., 2004) because it can increase plant vigor, production, resistance to root pathogens and tolerance of inclement weather and physiological disorders (SANTOS; GOTO, 2003). Ito et al. (2008) tested 11 squash rootstocks in muskmelon grafting experiments and observed that four of them were significantly effective in reducing gummy stem blight.

Despite the potential of grafting for disease control in the cultivation of melons and other cucurbits, this technique has rarely been studied, and the few studies that have been undertaken have primarily involved airborne pathogens. Therefore, the aim of this study was to evaluate the effect of grafting on the control of gummy stem blight in muskmelon hybrids using rootstocks from plants that are immune to D. bryoniae.

To evaluate the effect of grafting on the control of gummy stem blight in muskmelon hybrids, two sets of experiments were performed. The first set of experiments was performed under greenhouse 
conditions. Rootstocks from the squash hybrid Shelper, which is immune to D. bryoniae (ITO et al., 2008), were used. Shelper is one of the most widely used hybrids for grafting cucurbits in Brazil and is one of the most suitable for grafting muskmelons (RIZZO et al., 2004). For the grafts, four major muskmelon hybrids grown in greenhouses in southern and southeastern Brazil were used: Bonus II, Sunrise, Louis and Prince hakusho. Seeds of the rootstock and graft hybrids were pre-germinated in a germinator and subsequently transferred to cells in polystyrene trays containing a planting substrate made up of charred pine bark and vermiculite. The trays were then maintained in a greenhouse. Grafting was performed when the rootstock and graft plants had produced their first true leaves. Prior to grafting, the rootstock plants were transferred to plastic pots containing $250 \mathrm{ml}$ of the same planting substrate. The cleft-grafting method was used (CAÑIZARES; GOTO, 2003). Soon after grafting, the plants were placed in a growth chamber with a relative humidity of approximately $90 \%$ and a temperature of approximately $28^{\circ} \mathrm{C}$ for ten days. The plants were subsequently transferred to the greenhouse, where they remained throughout the experiment.

Ten days after the plants were placed in the greenhouse, they were inoculated with the pathogen using the toothpick method (VERZIGNASSI et al., 2004). The D. bryoniae isolate used in these studies was the UEM F12. The live culture is being maintained at the Micoteca/UEM, whose pathogenicity has been shown on identical host plants, was isolated from cultivated muskmelon plants and induces symptoms typical of gummy stem blight. To produce the inoculum, the D. bryoniae isolate was grown on potato dextrose agar (PDA) in an incubator for seven days. For inoculation, $0.5 \mathrm{~cm}$ diameter discs of mycelium containing PDA were removed from the peripheral region of the colonies. Using the tip of one half of a toothpick, each disc of PDA medium was individually inserted into a plant stem. The plants were then placed in a moist chamber for 24 hours and subsequently transferred to the greenhouse.
The treatments consisted of plants of each melon hybrid and of the squash hybrid Shelper, inoculated as follows: melon plants grafted onto the squash hybrid Shelper and inoculated at the hypocotyl of the graft, grafted melon plants and inoculated at the union graft/rootstock region, grafted melon plants and inoculated at the hypocotyl of the rootstock, ungrafted melon plants inoculated at the hypocotyl and ungrafted squash hybrid Shelper plants inoculated at the hypocotyl. Each treatment included six replicates, and the experimental design was completely randomized.

Evaluations began two days following inoculation and were repeated every four days up to 28 days post-inoculation (DPI). Symptoms were quantified by measuring the transverse and longitudinal lengths of the lesion caused by the pathogen. Lesions were considered to include the necrotic areas and areas of watery tissue surrounding the necrosis. The disease severity for each plant was calculated by multiplying the two measured lengths of the lesion and dividing the product by two to generate the approximate area of the lesion in square centimeters. An analysis of variance ( $F$ test) was used to analyze the data, and the treatment averages were grouped using the Scott-Knott test of SASM-Agri at 5\% probability (CANTERI et al., 2001). The success of the grafting technique was also evaluated, and the success ratio was expressed as a percentage.

In the second set of experiments, the effect of grafting on gummy stem blight was studied using the same muskmelon and squash hybrids as in the previous experiment. The four melon hybrids were grown in a protected environment consisting of a plastic hoophouse. To produce the grafted melon plants, the same procedures used in the first experiment were followed, and the squash hybrid Shelper was used as the rootstock. After grafting, the plants were kept in the greenhouse for 20 days and then transplanted to the plastic hoophouse.

The technical recommendations of Brandão Filho and Vasconcellos (1998) were followed in cultivating the four melon hybrids. Organic 
and chemical fertilizers were applied before transplanting the seedlings, and additional chemical fertilizer was applied as a covering. The seedlings were transplanted into raised beds, which were distributed in rows with $0.5 \mathrm{~m}$ between plants and 1.0 $\mathrm{m}$ between rows. Plants were supported by a single rod, vertically trained and pruned weekly to leave two secondary stems and one fruit per stem. Weed control was performed manually using hoes, and pest control was performed using insecticides. Irrigation was performed via scheduled drip irrigation.

The treatments included the four melon hybrids grafted onto squash hybrid Shelper rootstocks and ungrafted plants. The experimental design consisted of a randomized block with six replicates per treatment and a utilized portion represented by six plants. Artificial pathogen inoculation was not performed; instead, infected crop debris from previous melon crops and surviving $D$. bryoniae in the soil were considered the sources of the inoculum. Evaluations began after the seedlings were transplanted and were repeated every 10 days starting as soon as the first symptoms of gummy stem blight were noted. The incidence of gummy stem blight was determined based on the number of plants with disease symptoms and was expressed as a percentage. Disease severity was determined by measuring the transverse and longitudinal lengths of the necrotic lesion on the stem of each plant. The disease severity of each plant was rated based on the average area of the necrosis. The incidence and severity data were used to plot temporal diseaseprogression curves, in which the variables studied were individually plotted (y) as a function of time (x). These graph were used to compare the behavior of these variables between the various treatments at corresponding time periods. An analysis of variance ( $F$ test) was used to analyze the data, and the treatment averages were grouped using the Scott-Knott test of SASM-Agri at 5\% probability (CANTERI et al., 2001).

Both experiments were repeated and no significant difference was found between them, the results of the first experiment are presented.
In the first set of experiments, which were conducted in the greenhouse, grafting significantly reduced the severity of gummy stem blight in the four muskmelon hybrids when the squash hybrid Shelper, which is immune to D. bryoniae, was used as the rootstock. At 28 DPI, the disease severity, expressed as the area of necrosis, was 43.4, 42.6, 19.3 and $18.3 \mathrm{~cm}^{2}$ on Sunrise, Bonus II, Louis and Prince hakusho plants, respectively, grafted onto the squash hybrid Shelper and inoculated at the hypocotyl of the graft. These data correspond to a $34.1 \%, 33.8 \%, 51.1 \%$ and $48.0 \%$ reduction in the disease severity of gummy stem blight in the four melon hybrids, respectively, compared to ungrafted plants. For the same graft-rootstock combinations when the pathogen was inoculated at the union graft/rootstock region, the disease severity of gummy stem blight was 30.1, 27.5, 18.2 and 17.0 $\mathrm{cm}^{2}$, respectively, corresponding to a $54.3 \%, 57.3 \%$, $54.1 \%$ and $44.6 \%$ reduction in disease severity (Table 1). These results indicate that the resistance conferred by the rootstock were partially transferred to the graft, not conferring immunity. There were also significant differences between the four melon hybrids. Gummy stem blight was less severe in the hybrids Louis and Prince hakusho, which are less susceptible than Sunrise and Bonus II. Similar behavioral patterns have been observed in the commercial cultivation of these four hybrids under protected environmental conditions. The ungrafted squash hybrid Shelper plants that were inoculated at the hypocotyl showed no symptoms of gummy stem blight. Ito et al. (2008) also observed a significant reduction in the severity of gummy stem blight in grafted melon plants when using eight different rootstocks that were immune to $D$. bryoniae. For root diseases in chili culture as Fusarium and Verticillium,grafting was used in the production process, where rootstocks conferred immunity to graft (SANTOS; GOTO, 2003). However, the gummy stem blight affects aerial organs of the plant but not the root system, therefore the immune rootstock grafting did not confer immunity to plants, but reduced the rate of disease's progress. 
Table 1. Gummy stem blight severity on four muskmelon hybrids grafted and ungrafted onto the squash hybrid Shelper immune to D. bryoniae twenty-eight days after inoculation under greenhouse conditions.

\begin{tabular}{|c|c|c|c|c|c|c|c|c|}
\hline \multirow{2}{*}{$\begin{array}{l}\text { Region of } \\
\text { inoculation }^{1}\end{array}$} & \multicolumn{8}{|c|}{ Severity $\left(\mathrm{cm}^{2}\right)^{3}$} \\
\hline & Sunrise & $\%^{2}$ & Bonus II & $\%$ & Louis & $\%$ & Prince hakusho & $\%$ \\
\hline 1 & $43.4 \mathrm{aA}$ & 34.1 & $42.6 \mathrm{aA}$ & 33.8 & $19.3 \mathrm{aB}$ & 51.1 & $18.3 \mathrm{aB}$ & 48.0 \\
\hline 2 & $30.1 \mathrm{bA}$ & 54.3 & $27.5 \mathrm{bA}$ & 57.3 & $18.2 \mathrm{aB}$ & 54.1 & $17.0 \mathrm{aB}$ & 44.6 \\
\hline 3 & $65.8 \mathrm{cA}$ & - & $64.3 \mathrm{cA}$ & - & $39.6 \mathrm{bB}$ & - & $38.1 \mathrm{bB}$ & - \\
\hline
\end{tabular}

${ }^{1} 1$ - grafted melon plants and inoculated at the hypocotyl of the graft; 2- grafted melon plants inoculated at the graft region: 3 ungrafted melon plants inoculated at the hypocotyl; ${ }^{2}$ Severity reduction (\%) into grafted plants; ${ }^{3}$ Means followed by the same lower case letters in the same column and means followed by the same upper case letters in the same row do not differ by Scott-Knott test $(\mathrm{P}<0.05)$.

The level of rootstock/graft compatibility (living grafts) was 99\%. High rates of living grafts are critical in the successful production of grafted seedlings. Ito et al. (2008) noted that rates of living grafts above $95 \%$ are considered good.

In the second set of experiments, which were conducted in a protected plastic hoophouse environment, the incidence of gummy stem blight at 15 days post-transplant (DPT) was 67.0\%, 33.0\%, $27.0 \%$ and $37.0 \%$ in the melon hybrids Sunrise, Bonus II, Louis and Prince hakusho, respectively, grafted onto the squash hybrid Shelper. For the same hybrids, the disease incidence in ungrafted plants was $83 \%, 53 \%, 47 \%$ and $40 \%$, respectively. Thus, grafting greatly reduced the incidence of disease compared to ungrafted plants, based on the onset of disease symptoms. At 40 DPT, however, the disease reached the maximum level of incidence $(100 \%)$ in nearly all of the treatments. The effect of grafting on the incidence of gummy stem blight occurred only in the early stages of the disease. At the end of the experiment (95 DPT), the disease incidence was greater than $97 \%$ in all four grafted and ungrafted melon hybrids, whereas at 25 DPT, only a majority of the plants were symptomatic (Figure 1).

The first symptoms of gummy stem blight appeared at 15 DPT in the grafted and ungrafted treatments. In grafted plants, the symptoms appeared only on the graft and not on the rootstock. The symptoms consisted primarily of necrosis, which appeared on the stem at or near the insertion of the cotyledons and progressed upward and outward. The early onset of symptoms coincided with the onset of cotyledon senescence. Gasparotto et al. (2011) observed that in muskmelon cultivation in protected environments in southern Brazil, the onset of the first symptoms of gummy stem blight was directly related to the senescence of the cotyledons.

In this study, when the muskmelon plants were cultivated under protected conditions in the plastic hoophouse, the effect of grafting on the disease severity of gummy stem blight was more pronounced. Grafting onto immune rootstocks reduced the disease severity of gummy stem blight by $34.3 \%$ to $49.4 \%$ in the four muskmelon hybrids (Table 2). Disease severity was greater in the ungrafted Sunrise and Bonus II plants but did not differ between these two hybrids. In addition, the effects of grafting did not differ significantly between these two hybrids, but a significant difference was observed between grafted and ungrafted plants. The same observations were true for the hybrids Louis and Prince hakusho. Among the four hybrids, there were two types of outcomes for both grafted and ungrafted plants. Sunrise and Bonus II had greater disease severity and were grouped together, whereas Louis and Prince hakusho had lesser disease severity and formed a separate group. 
Figure 1. Gummy stem blight incidence (\%) on four muskmelon hybrids (Sunrise, Bonus II, Louis and Prince hakusho) grafted and ungrafted onto the squash hybrid Shelper immune to Didymella bryoniae cultivated under protected environment.

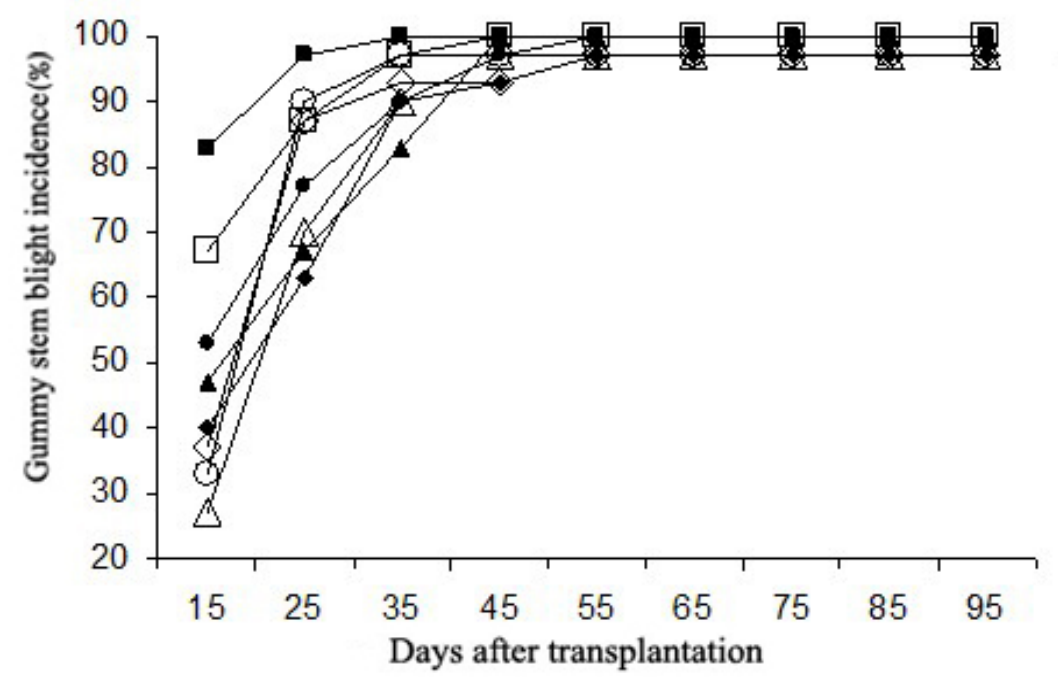

Hybrids

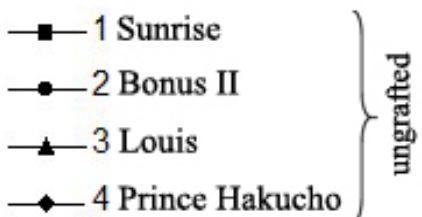

$\square-5$ Sunrise

-6 Bonus II

$\triangle 7$ Louis

$\smile 8$ Prince Hakucho

Table 2. Gummy stem blight severity on four muskmelon hybrids grafted and ungrafted onto the squash hybrid Shelper immune to D. bryoniae cultivated under protected environment.

\begin{tabular}{cccc}
\hline \multirow{2}{*}{ Hybrids } & \multicolumn{3}{c}{ Severity $\left(\mathrm{cm}^{2}\right)$} \\
\cline { 2 - 4 } & Grafted & Ungrafted & Percentage of control* \\
\hline Sunrise & $23.5 \mathrm{aA}$ & $35.8 \mathrm{aB}$ & 34.3 \\
Bonus II & $21.3 \mathrm{aA}$ & $32.5 \mathrm{aB}$ & 34.8 \\
Louis & $11.6 \mathrm{bA}$ & $21.2 \mathrm{bB}$ & 45.8 \\
Prince hakusho & $11.9 \mathrm{bA}$ & $22.5 \mathrm{bB}$ & 49.4 \\
CV (\%) & & & - \\
\hline
\end{tabular}

Means followed by the same lower case letters in the same column and means followed by the same upper case letters in the same row do not differ by Scott-Knott test $(\mathrm{P}<0.05)$. "Severity reduction (\%) in grafted plants.

With regard to the efficacy of grafting in controlling gummy stem blight under both greenhouse and protected hoophouse conditions, the disease severity was reduced in all four hybrids. The reduction in disease severity ranged from $34.1 \%$ to $34.7 \%$ in the hybrid Sunrise, from $33.8 \%$ to $34.8 \%$ in the hybrid Bonus II, from $45.8 \%$ to $51.1 \%$ in the hybrid Louis and from $48.0 \%$ to $49.4 \%$ in the hybrid Prince hakusho. No symptoms of gummy stem blight were observed when the pathogen was inoculated onto the hypocotyl of the squash hybrid Shelper rootstock.

The disease progress curves showed the dynamic effect of grafting on the progression of gummy stem blight during the crop cycle (Figure 2). As stated above, the first disease symptoms were observed at 15 DPT. Over the course of the crop cycle, the grafted plants showed less disease development. The ungrafted Sunrise melon plants clearly showed more rapid disease progression. 
Figure 2. Gummy stem blight progress curves on four muskmelon hybrids (Sunrise, Bonus II, Louis and Prince hakusho) grafted and ungrafted onto the squash hybrid Shelper immune to Didymella bryoniae cultivated under protected environment.

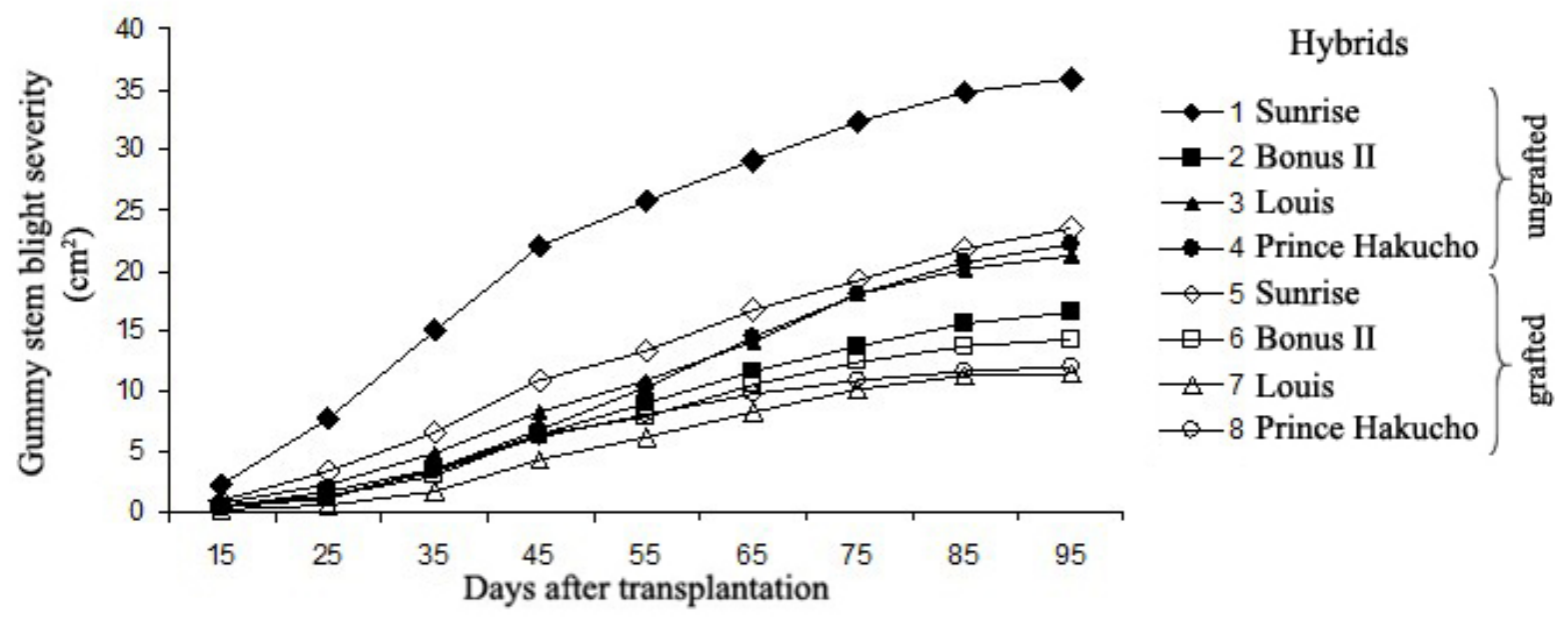

A comparison of the disease severity and disease incidence curves shows that at 75 DPT, approximately $90 \%$ of the plants exhibited disease symptoms. However, the disease severity was approximately $7.0 \%$ in grafted Louis and Prince hakusho melon plants. This level can be considered low for gummy stem blight. Notably, muskmelon fruit begin their physiological maturation at 75 DPT, and the risk of damage caused by gummy stem blight becomes much smaller.

The disease severity was greater for both grafted and ungrafted plants in the greenhouse experiments than under the protected environment experimental conditions. These results were most likely due to the greater inoculum potential of artificial inoculation and the more favorable environmental conditions for successful infection and disease development. The disease severity of gummy stem blight was much lower in the hybrids Louis and Prince hakusho than in the hybrids Sunrise and Bonus II. The former two hybrids exhibit higher field resistance compared to the latter two hybrids. These data show that grafting has increased practical value when combined with a higher level of genetic resistance. The grafting technique may also have an additive effect when combined with other control measures, such as fungicide use.
In conclusion, grafting onto immune rootstocks significantly reduced the severity of $D$. bryoniae in four muskmelon hybrids grown under greenhouse and protected environment conditions. Moreover, grafting and innate genetic resistance exhibited an additive effect in reducing the disease severity of gummy stem blight.

\section{Acknowledgments}

The authors acknowledge the scholarships granted by Coordenação de Aperfeiçoamento de Pessoal de Nível Superior (CAPES) and Conselho Nacional de Desenvolvimento Científico e Tecnológico (CNPq).

\section{References}

BRANDÃO FILHO, J. U. T.; VASCONCELLOS, M. A. S. A cultura do meloeiro. In: GOTO, R.; TIVELLI, S. W. (Ed.). Produção de hortaliças em ambiente protegido: condições subtropicais. São Paulo: Fundação Editora UNESP, 1998. p. 161-194.

CAÑIZARES, K. A. L.; GOTO, R. Enxertia em cucurbitáceas. In: GOTO, R.; SANTOS, H. S.; CAÑIZARES, K. A. L. (Ed.). Enxertia em hortaliças. São Paulo: Fundação Editora UNESP, 2003. p. 55-56. 
CANTERI, M. G.; ALTHAUS, R. A.; VIRGENS FILHO, J. S. das; GIGLIOTI, E. A.; GODOY, C. V. SASM-Agri: sistema para análise e separação de médias em experimentos agrícolas pelos métodos Scott-Knott, Tukey e Duncan. Revista Brasileira de Agrocomputação, Ponta Grossa, v. 1, n. 2, p. 18-24, 2001.

GASPAROTTO, F.; VIDA, J. B.; TESSMANN, D. J.; ALVES, T. C. A. A. Latent infection by Didymella bryoniae in muskmelon. Summa Phytopathologica, Botucatu, v. 37, n. 1, p. 62-64, 2011.

ITO, L. A.; BRAZ, L. T.; CASTOLDI, R.; CHARLO, H. C. O. Response of rootstocks to stem canker and the production e quality of melon under protected cultivation. Acta Horticulturae, Belgium, v. 771, p. 151-155, 2008.

KUROZAWA, C.; PAVAN, M. A.; REZENDE, J. A. M. Doenças das cucurbitáceas. In: KIMATI, H.; AMORIM, L.; REZENDE, J. A. M.; BERGAMIN FILHO, A.; CAMARGO, L. E. A. (Ed.). Manual de fitopatologia: doenças das plantas cultivadas. 4. ed. São Paulo: Editora Agronômica Ceres, 2005. v. 2, p. 293-310.

RIZZO, A. A. N.; CHAVES, F. C. M.; LAURA, V. A.; GOTO, R. Avaliação de métodos de enxertia e portaenxertos para melão rendilhado. Horticultura Brasileira, Brasília, v. 22, n. 4, p. 808-810, 2004.

SANTOS, H. S.; GOTO, R. Enxertia em hortaliças. In: GOTO, R.; SANTOS, H. S.; CAÑIZARES, K. A. L. (Ed.). Enxertia em hortaliças. São Paulo: Fundação Editora UNESP, 2003. p. 9-11.
VERZIGNASSI, J. R.; VIDA, J. B.; GASPAROTTO, F.; CORTEZ, G. L. S.; LORENZETTI, E. R.; FARIA, G. S.; TESSMANN, D. J.; SEVERINO, J. J. Método do palito para inoculação de Didymella bryoniae em melão nobre e pepino partenocárpico. In: CONGRESSO BRASILEIRO DE FITOPATOLOGIA, 37., 2004, Gramado. Anais... Gramado: Sociedade Brasileira de Fitopatologia, 2004. p. $154 \mathrm{~S}$.

VIDA, J. B.; TESSAMANN, D. J.; ZAMBOLIM, L.; VERZIGNASSI, J. R.; BRANDÃO FILHO, J. U. T. Controle da podridão gomosa em melão rendilhado em cultivo protegido por sanitização de ferramenta de poda. Fitopatologia Brasileira, Brasília, v. 29, n. 6, p. 626-631, 2004b.

VIDA, J. B.; VERZIGNASSI, J. R.; TESSAMNN, D. J.; OLIVEIRA, R. R.; CAIXETA, M. P.; NUNES, W. M. C. Manejo de doenças de plantas em cultivo protegido. Fitopatologia Brasileira, Brasília, v. 29, n. 4, p. 355-372, $2004 a$.

VIDA, J. B.; ZAMBOLIM, L.; VALE, F. X. R.; COSTA, H. Manejo de doenças em cultivos protegidos. In: ZAMBOLIM, L. (Ed.). Manejo integrado: fitossanidade - cultivo protegido, pivô central e plantio direto. Viçosa, MG: UFV, 2001. p. 53-118. 